\title{
LA REPRESENTACIÓN DEL HORROR EN LA PANTALLA TELEVISIVA ARGENTINA: TESTIMONIOS DE SOBREVIVIENTES DE LA ÚLTIMA DICTADURA MILITAR Y LUGARES DE DESAPARICIÓN
}

The representation of horror in the argentinian tv: testimonies of the last military dictatorship survivors and places of disappearance

\author{
MALENA CORTE \\ CIS-IDES/CONICET (ARGENTINA) \\ malecorte@gmail.com http://orcid.org/0000-0001-5372-1977
}

RECIBIDO: 29 DE ABRIL DE 2018

ACEPTADO: 19 DE FEBRERO DE 2019

RESUMEN: Desde el regreso a la democracia en la Argentina (1983), la temática del pasado reciente dictatorial ha sido abordada extensamente por el formato audiovisual, especialmente a través del cine, pero también en televisión. A partir de diversos abordajes y géneros se ha intentando representar aquello que era impensado e inimaginado para la sociedad. Los crímenes, las desapariciones y el horror de los centros clandestinos de detención fueron tempranamente representados por distintas producciones audiovisuales. En el presente artículo nos proponemos analizar cómo los documentales televisivos de Canal Encuentro han representado los lugares de desaparición en relación con la palabra de sobrevivientes de la última dictadura.

PALABRAS CLAVE: Televisión, Sobrevivientes, Testimonio, Lugares de desaparición, Argentina.

ABSTRACT: Since the return of democracy in Argentina (1983), the subject of the recent dictatorial past has been extensively addressed by audiovisual formats, especially through cinema, but also through television. From different approaches and genres, they have tried to represent what was unthinkable and unimaginable by the society. The crimes, disappearances and horror of the clandestine detention centers were early represented by different audiovisual productions. In this article we intend to analyze how television documentaries of Encuentro Channel have represented the places of disappearance in relation to the testimonies of the survivors of the last dictatorship.

KEY WORDS: Television, Survivors, Testimony, Places of disappearance, Argentina. 


\section{INTRODUCCIÓN ${ }^{1}$}

Desde el regreso a la democracia en la Argentina (1983), la temática del pasado reciente dictatorial ha sido abordada extensamente por el formato audiovisual, especialmente a través del cine, pero también en televisión. A partir de diversos abordajes y géneros se ha intentando representar aquello que era impensado e inimaginado para la sociedad. Los crímenes, las desapariciones y el horror de los centros clandestinos de detención fueron tempranamente representados por distintas producciones audiovisuales.

Durante los mandatos de Néstor Kirchner (2003-2007) y Cristina Fernández de Kirchner (2007-2011; 2011-2015), en Argentina se activaron numerosas estrategias gubernamentales vinculadas a la realización de contenidos televisivos. En esta línea, es importante mencionar que se crearon nuevos canales públicos de televisión: Canal Encuentro en 2005, INCAA TV y Pakapaka en 2010, TECtv en 2012 y DeporTV en 20132. Asimismo, en 2009 se implementó la Televisión Digital Abierta $(\mathrm{TDA})^{3}$, servicio que ofrece un paquete de señales digitales satelitales gratuitas, para lo cual también se crearon nuevos canales digitales y se abrieron concursos nacionales para financiar la realización de programas. De esta manera, observamos que el mismo Estado se convirtió en un gran productor de contenidos audiovisuales.

Frente a este contexto, nuestro interés reside en las producciones televisivas referidas a la última dictadura militar (1976-1983) impulsadas por Canal Encuentro. Específicamente, nos centraremos en aquellas que incluyan testimonios de sobrevivientes de centros clandestinos de detención: se trata de las series "Ex - ESMA. Retratos de una recuperación” (2014), "A la sombra del Aconcagua. Historia del terrorismo de Estado en Mendoza" (2015) y "El camino de la justicia" (2015)4. A partir de su análisis, nos interesa reflexionar sobre la relación entre testimonios y lugares de desaparición. A continuación, entonces, realizaremos una caracterización de las series televisivas en cuestión, reflexionaremos sobre el género documental y luego examinaremos las dos formas principales que presentan los testimonios en relación a los lugares de desaparición: el reconocimiento espacial y su marcación. La hipótesis que nos guiará propone que las series

\footnotetext{
1 Este artículo se enmarca dentro de un proyecto de tesis más amplio que tiene como objetivo el análisis de las producciones audiovisuales sobre la última dictadura militar que han sido promovidas por Canal Encuentro en el período 2005-2015.

2 Encuentro era un canal educativo y cultural del Ministerio de Educación de la Nación. Pakapaka y DeporTV también dependían de ese Ministerio y se dedicaban a contenidos infantiles y deportivos, respectivamente. Por su parte, INCAA $T V$ era el canal del Instituto Nacional de Cine y Artes Audiovisuales y se dedicaba al cine argentino (recientemente modificó su nombre a Cine.ar) y TECtv es un canal de divulgación científica que depende del Ministerio de Ciencia, Tecnología e Innovación Productiva.

${ }^{3} \mathrm{La}$ TDA es un programa del Estado que cubre aproximadamente el $85 \%$ del territorio nacional y, básicamente, consiste en un servicio que ofrece un paquete de señales digitales satelitales gratuitas. Para acceder a su programación es necesario un decodificador que transforme la señal analógica en digital, o bien, poseer un televisor con equipo receptor integrado.

${ }^{4}$ Específicamente, se trata de los capítulos "Un átomo en el universo infinito congelado", "Conmorir", "Sobrevivir", "Vida aparecida", "Espacio/Memoria" y "Memoria y futuro" de "Ex - ESMA. Retratos de una recuperación", el episodio "Centros Clandestinos" de la serie "A la sombra del Aconcagua. Historia del terrorismo de Estado en Mendoza" y los capítulos "Nunca Más" y "Sitios de memoria" del programa "El camino de la justicia".
} 
televisivas plantean la necesidad de que los testimonios, en el momento de tematizar los lugares de desaparición, cuenten con algún tipo de anclaje material para evocar el pasado, lo que nos llevará a reflexionar sobre los vínculos entre materialidad y testimonio.

\section{SERIES TELEVISIVAS Y TESTIMONIOS DE SOBREVIVIENTES: UNA BREVE CARACTERIZACIÓN}

Antes de adentrarnos en la caracterización de las series televisivas objeto de nuestro estudio, resulta pertinente presentar brevemente el canal que las ha puesto al aire, ya que presenta algunas singularidades. Para empezar, Encuentro fue el primer canal de televisión del Ministerio de Educación de la Nación ${ }^{5}$ y funcionaba en el marco de una Sociedad del Estado que era Educ.ar ${ }^{6}$. Fue creado en 2005 por el Decreto 533/05, en 2006 fue reconocido por la Ley de Educación Nacional 26.206 y comenzó su transmisión el 5 marzo de 20077. Como se observa, se trata de un canal público, lo que implica algunas características distintivas, como, por ejemplo, el hecho de que sus lineamientos editoriales y sus contenidos eran planificados desde el Ministerio de Educación. De hecho, también formaba parte de sus objetivos hacer llegar sus programas a las aulas de los colegios de todo el país a través del envío de colecciones de $d v d s$ y material didáctico ${ }^{8}$.

Asimismo, otra particularidad del canal consiste en su modalidad de producción delegada. Es decir, Encuentro tiene un diseño de producción que consiste en delegar la realización de los programas en otros actores, básicamente en casas productoras o en universidades que tienen centros de producción audiovisual. Esto implica, entonces, que las tres series que presentaremos a continuación fueron producidas por casas productoras totalmente diferentes, a las que Encuentro delegó su realización. No obstante esta variedad de productoras con las que trabaja el canal, debe aclararse que no hay un deslinde del proceso creativo ni de la producción en términos generales, dado que existe una figura dentro del canal, llamada productor delegado, que se encarga de realizar el seguimiento de cada programa junto con la casa productora elegida9.

Ahora bien, hechas algunas aclaraciones vinculadas al canal que emitió los programas televisivos en cuestión, pasaremos a continuación a describir sus principales características. La primera producción audiovisual que analizaremos, "Ex - ESMA..." es una serie documental que

\footnotetext{
${ }^{5}$ Hablamos en términos pasados ya que a partir de la asunción del nuevo gobierno nacional a fines de 2015 el canal dejó de pertenecer al Ministerio de Educación y pasó a formar parte del Sistema Federal de Medios y Contenidos Públicos.

${ }^{6}$ Educ.ar es el portal educativo del Ministerio de Educación, según figuraba en su sitio web: "Es un sitio con contenidos, plataforma de formación a distancia y otros servicios del mundo digital destinados a docentes, alumnos, familias, directivos, investigadores y organizaciones para incorporar las TIC (tecnologías de la información y la comunicación) a la educación de la Argentina”.

${ }^{7}$ Para ampliar la información sobre la historia del canal, puede consultarse Smerling (2015) y Corte (2016).

8 Véase Corte (2016) para un análisis sobre el componente educativo del canal.

${ }^{9}$ La caracterización y análisis en profundidad de este particular modo de producción forma parte de nuestra tesis en curso.
} 
cuenta con ocho capítulos ${ }^{10}$ de 26 minutos cada uno. La dirección estuvo a cargo de Benjamín Ávila y la productora fue Habitación 152011. Su estreno fue el 24 de marzo ${ }^{12}$ de 2014 a las 22:30 horas ${ }^{13}$.

El programa está basado en testimonios: fundamentalmente sobrevivientes de la ESMA ${ }^{14}$ y madres e hijos de desaparecidos. Asimismo, se incluye la palabra de especialistas en historia argentina reciente, fiscales, coordinadores y miembros de diferentes áreas del predio de la Ex-ESMA. Además de estos testimonios y relatos, también se incluyen imágenes de archivo como fotografías, planos, mapas, publicidades y otros audiovisuales de época, audios de discursos presidenciales, fragmentos de films, así como dibujos realizados por la artista plástica María Giuffraa ${ }^{15}$. En cuanto a la locación de las filmaciones, hay algunas actuales del interior y exterior de la ex-ESMA, en particular, del exCasino de Oficiales ${ }^{16}$ y otras tomadas en un estudio, donde tuvieron lugar los testimonios.

Si bien la serie incluye los diferentes tipos de imágenes que recién mencionamos, los testimonios constituyen lo primordial del documental. Su centralidad está dada fundamentalmente por dos cuestiones: la primera refiere a la cantidad de minutos dedicados a ellos y, la segunda, a su protagonismo visual. En relación a la primera, a lo largo de cada capítulo, oímos prácticamente sin pausas el relato de los testimoniantes y especialistas, ya que no hay voz en off que narre y acompañe el desarrollo del programa, como suele ocurrir en los documentales clásicos. Aquí, son los testimonios los que dan voz a las imágenes y los que guían el relato. La ausencia de un narrador, a su vez, destaca

${ }^{10}$ Cuando comenzó el proyecto de la serie se había estipulado la realización de un solo capítulo y luego evaluaron la posibilidad de hacer cuatro, pero por la gran cantidad de material recopilado finalmente decidieron concretar ocho.

11 Benjamín Ávila es director de cine y socio fundador, junto a Lorena Muñoz y Maximiliano Dubois, de la productora Habitación 1520, que desde hace más de diez años se dedica a la realización de cine y televisión.

$12 \mathrm{El} 24$ de marzo es el día en que se conmemora el inicio de la dictadura en 1976. Desde 2006 ha sido establecido como feriado nacional para conmemorar el Día de la Memoria, la Verdad y la Justicia.

13 Los capítulos son: "Historia y golpes", "El enemigo interno", "Un átomo en el universo infinito congelado", "Conmorir", "Sobrevivir", "Vida aparecida", "Espacio/Memoria" y "Memoria y futuro". El día del estreno se transmitió el anteúltimo episodio. Unos meses después, cuando la serie completa estuvo terminada, el canal la puso al aire a partir del 19 de mayo, los días lunes en el mismo horario, respetando el orden de los capítulos que recién expusimos.

$14 \mathrm{La}$ Escuela de Mecánica de la Armada (ESMA) fue el centro clandestino más grande del país. Se estima que aproximadamente 5000 detenidos-desaparecidos pasaron por allí. En 2004 fue convertido en el Espacio para la Memoria y para la Promoción y Defensa de los Derechos Humanos.

15 Giuffra, que es hija de desaparecidos, realiza estos dibujos a partir de múltiples líneas blancas, con trazos agresivos, que logran el efecto como de rayado. Estos dibujos están en movimiento y por lo general tienen una función ilustrativa. Excede los objetivos de nuestro trabajo analizar la obra de la artista, pero sí es pertinente señalar que Giuffra ya había tenido experiencia en el mundo audivisual: realizó un cortometraje animado, "La matanza", y participó con sus dibujos en el film "El tiempo y la sangre". Para un análisis de ello, véase Amado (2005) y Arreche (2015).

16 El Casino de Oficiales era el edificio donde se mantenía en cautiverio a los desaparecidos. Cabe aclarar que especialmente para la filmación de la serie se retiraron todas las infografías, cartelerías y demás marcaciones del Instituto Espacio para la Memoria (IEM) que había en el ex-Casino de Oficiales con el objetivo de filmar el lugar sin ningún tipo de "agregado". Si bien, para ese momento todavía no estaba inaugurado el Museo Sitio de Memoria ESMA tal cual existe hoy, sí había algunas señalizaciones y el público podía visitarlo (sobre estas cartelerías, puede consultarse Feld, $2012 ; 2017$ y Guglielmucci, 2013). Como comentan los entrevistados, el permiso para retirar estas marcaciones fue difícil de conseguir, pero finalmente pudieron obtenerlo y de esta manera, se tomaron las últimas imágenes del lugar sin ningún tipo de cartelería. Entrevista a Graciela Dobal, productora periodística, realizada por la autora (Fecha: 19/04/16). Entrevista a trabajador de Encuentro, realizada por la autora (Fecha: 01/12/15). 
un lugar de enunciación fuertemente subjetivo, como si los hechos fueran contados por los sobrevivientes directamente al espectador, sin mediaciones. La segunda cuestión consiste en la centralidad del testimonio en la pantalla: aún cuando se incorporan otras imágenes, la figura del testimoniante suele tener mayor protagonismo a nivel visual. En cuanto a los contenidos generales, la serie realiza a lo largo de sus episodios un recorrido histórico progresivo que arranca con el origen de la ESMA, luego focaliza en la última dictadura y culmina con dos capítulos dedicados al período que se abre con el regreso a la democracia.

El segundo programa televisivo, "A la sombra del Aconcagua...", es una serie dedicada fundamentalmente al abordaje del terrorismo de Estado en la provincia de Mendoza. La productora es Liberar Contenidos y su director, Rodrigo Sepúlveda17. El programa se emitió en Encuentro dado que resultó ganador de un concurso impulsado por INCAA y Educ.ar S.E en el año $2012^{18}$ y se estrenó en 2015, año en el cual se transmitió durante los meses de junio y julio, los lunes a las 18.30 hrs.

"A la sombra del Aconcagua..." cuenta con ocho capítulos de aproximadamente media hora cada uno19. La serie comienza con los sucesos del "Mendozazo" que tuvieron lugar en 1972 y culmina con los juicios a los jueces del año 2014 y los juicios de lesa humanidad del 2010. A diferencia de la primera serie que presentamos, este programa cuenta con la figura de un narrador. Se trata de la voz en off de una mujer que desde el comienzo y a lo largo de todos los capítulos es la encargada de ordenar el relato y llevar adelante el tema específico abordado. Mientras observamos imágenes audiovisuales de archivo, fotografías, portadas de diarios, así como imágenes actuales de ex centros clandestinos de detención, la narradora ubica temporalmente al espectador, dando información y contextualizando la situación particular de la provincia de Mendoza. A su vez, en algunas oportunidades, presenta los testimonios y agrega información sobre lo que ellos relatan o sobre otros casos similares.

En la mayoría de los capítulos aparece la palabra de especialistas en la historia en cuestión, así como testimonios de dirigentes, estudiantes y trabajadores de aquella época, integrantes de organismos de derechos humanos, funcionarios judiciales y del poder ejecutivo, abogados, familiares y amigos de desaparecidos, y sobrevivientes ${ }^{20}$. Particularmente, en el capítulo en el que aparece la palabra de los sobrevivientes ("Centros clandestinos") y por tanto aquel que analizaremos aquí,

\footnotetext{
17 Sepúlveda es un periodista, escritor y documentalista mendocino.

18 Estos concursos surgieron a partir de los convenios de cooperación firmados en 2012, entre el Ministerio de Educación de la Nación y el Instituto Nacional de Cine y Artes Audiovisuales, mediante el cual el Ministerio y el INCAA convocaron a la realización de doce series documentales para ser emitidas, seis en Canal Encuentro y otras seis en Pakapaka. En concreto, se eligió un proyecto por cada región del país para cada canal: Centro Metropolitano, Centro Norte, NEA, NOA, Nuevo Cuyo y Patagonia. Resoluciones N²875/2012 y N²823/2012.

19 Los capítulos son: "El Mendozazo", "Comandos parapoliciales", "El golpe en Mendoza”, "La represión en el periodismo", "Centros clandestinos", "La resistencia de las Madres”, "El juicio a los jueces” y "Justicia y reparación”.

20 Vale aclarar que no sólo se presentan estos testimonios producidos especialmente para la serie, sino que también se utiliza material de dos documentales previos realizados por el mismo director del programa: el mediometraje "7746 Legajo CONADEP” del año 2006 y el documental “D2” de 2001.
} 
notamos que los testimonios tienen gran protagonismo: queda en un segundo plano la voz en off y directamente no se incluye material de archivo.

El tercer y último programa que analizaremos, "El camino de la justicia", es una serie de cinco capítulos dedicada a abordar los procesos judiciales vinculados a los crímenes cometidos por la dictadura, con énfasis en la historia y lucha de los organismos de derechos humanos de la provincia de Córdoba. Sus capítulos ${ }^{21}$ duran aproximadamente treinta minutos cada uno y fueron transmitidos por Encuentro a partir de agosto de 2015, los lunes a las 22 hrs. Los directores fueron Claudio Rosa y Santiago $\operatorname{Sein}^{22}$ y la producción la realizó Bonaparte Cine $^{23}$.

Si bien sus episodios se dividen en función de temas, la serie tiene un recorrido histórico progresivo bien definido: comienza en la dictadura y su final, pasa luego por los ochenta y noventa y culmina en su último capítulo con diversos acontecimientos sucedidos a partir del año 2003. A lo largo de los capítulos se da gran importancia a la conformación de H.I.J.O.S Regional Córdoba y a sus acciones políticas en los diferentes contextos históricos del país. El primer episodio, "Nunca más", es el único que no se dedica a eso, sino que está focalizado en la dictadura y en el momento inmediatamente posterior, incluyendo testimonios de ex detenidos-desaparecidos y es por esto último que será el que analizaremos en profundidad en este trabajo.

En esta serie, el testimonio también comparte el protagonismo con un narrador en off y con material de archivo, que tiene un rol preponderante, más marcado que en los ciclos analizados anteriormente. En "El camino de la justicia" no hay entrevistas a especialistas como recurso de contextualización, explicación y legitimación de un relato, sino que esta tarea de descripción la lleva adelante el narrador junto con los testimonios de familiares y sobrevivientes ${ }^{24}$. El narrador, al igual que la serie anterior, también va llevando el argumento de cada capítulo, describiendo los sucesos acontecidos en Córdoba mientras las imágenes de archivo ilustran. Sin embargo, aquí la voz en off no presenta ni da información sobre los testimoniantes, de modo que hay una diferencia marcada entre las secciones dedicadas a estos y los fragmentos en donde el narrador, con el material de archivo, realiza una reconstrucción histórica.

A partir de la descripción que hemos realizado, observamos que los documentales difieren en algunas cuestiones vinculadas a los recursos narrativos, como son la utilización de voz en off, la inclusión de entrevistas a especialistas y el distinto énfasis dado al material de archivo. Sin embargo,

\footnotetext{
21 Estos son: "Nunca más", "Los hijos", "La condena social”, "Juicios por la verdad” y "Sitios de memoria”.

22 Ambos son licenciados en cine y televisión por la Universidad Nacional de Córdoba y junto a Romina Savary, son socios fundadores de la productora Bonaparte Cine.

23 Se trata de una productora cordobesa dedicada desde 2011 a la realización de contenidos audiovisuales de género documental, animación y ficción. La producción se realizó junto a la Universidad Nacional de Córdoba y SRT multimedio, y participaron Abuelas de Plaza de Mayo filial Córdoba, Comisión y Archivo Provincial de la Memoria de Córdoba, Familiares de Desaparecidos y Detenidos por Razones Políticas de Córdoba e H.I.J.O.S Regional Córdoba.

${ }^{24}$ Cabe aclarar que sí son entrevistados abogados de organismos de derechos humanos y un periodista, pero lo que buscamos señalar es que, a diferencia de las otras series, aquí no se incluye la palabra de historiadores, sociólogos e incluso periodistas con el objetivo de abordar el contexto histórico del país ni para dar cuenta de procesos sociales más amplios. Los abogados y el periodista consultados aquí se refieren a casos específicos.
} 
más allá de estas diferencias, encontramos en estos capítulos una constante: la proyección de testimonios de sobrevivientes, y es por esto que nos ha resultado interesante elegirlos para el análisis. A continuación, entonces, nos focalizaremos en examinar estos testimonios en relación a los lugares de desaparición.

\section{REPRESENTAR EL HORROR: TESTIMONIOS Y LUGARES DE DESAPARICIÓN}

Ya presentadas las series, nos dedicaremos ahora a analizar cómo estas incluyen los testimonios de sobrevivientes y cómo representan específicamente los lugares de desaparición. En este sentido, nos preguntamos: ¿Cómo aparecen estos lugares en los testimonios? ¿Cómo se construye una verdad sobre lo sucedido? ¿Cómo se relaciona el testimonio con la materialidad? ¿Esto implica revivir el horror padecido? Para responder nuestros interrogantes resulta fundamental atender primero a dos cuestiones: por un lado, al género utilizado por las series y, por otro, a las particularidades del caso argentino en relación a la (in)existencia de imágenes del horror.

En primer lugar, debemos considerar que, como parte de aquello que Huyssen denominó "cultura de la memoria" (2007:19), comenzó hacia la década de los setenta a nivel mundial una revalorización del pasado que no sólo implicó un culto a lo vintage (Huyssen, 2007) y una obsesión por conservar y documentar (Baer, 2006), sino que también supuso la proliferación de producciones audiovisuales dedicadas al pasado. Más específicamente, a raíz del genocidio cometido por el nazismo, el cine y, en menor medida la televisión, intentaron representar y abordar hechos de violencia en $\operatorname{masa}^{25}$.

En Argentina, el cine tempranamente se aproximó a lo sucedido en la última dictadura militar. Y si bien las películas más emblemáticas del regreso a la democracia fueron ficciones (como "La historia oficial" y "La noche de los lápices"), por lo general fue el género documental el que mayormente abordó el pasado reciente dictatorial. En el caso de las tres series televisivas que analizaremos se trata de documentales, por lo que es necesario reflexionar sobre este género. Por empezar, no debemos perder de vista que, así como la ficción, los documentales también son construcciones sociales. Para Niney (2009), las diferencias entre ambos están relacionadas con el nivel de control que el realizador tiene sobre la puesta en escena. Lo que resulta caracaterístico del documental es que las estrategias empleadas apuntan a enfatizar el carácter indicial de las imágenes registradas.

Como bien explica Nichols (2011), "los documentales suelen invitarnos a aceptar como verdadero lo que los sujetos narran acerca de algo que ha ocurrido [...]” (2011:51), de modo que el mismo género colabora en la construcción de un pacto de verdad con el espectador, quien se predispone a ver este tipo de formato esperando ser informado con cuestiones pertenecientes a la realidad. Según el autor, una de las expectativas fundamentales de este género es que "los sonidos y

25 Para un análisis sobre las discusiones más amplias surgidas en tono a la (im)posibilidad de representar experiencias límite, véase Adorno (1962), Wiesel (1985), Traverso (2001), Didi Huberman (2004), LaCapra (2005; 2009), Baer (2006), Friedlander (2007), Huyssen (2007; 2009), Rancière (2013), entre otros. 
las imágenes tienen una relación indicativa con el mundo histórico” (2011:58). De esta manera, las imágenes de los hechos tendrían una legitimidad más indiscutible que la ficción ${ }^{26}$, que representa lo sucedido en vez de presentarlo. Relacionado con esto, para Baer (2005), "las imágenes conservan un estatus privilegiado que continúa legitimando su utilización como eficaz vehículo de significaciones, como instrumentos de registro y representación neutrales, objetivos y veraces" (2005: XXI). Asimismo, como señala Aprea (2012a), el modo de hacer verosímil lo expuesto en los documentales potencia la idea de que se basan en una realidad preexistente y apela a la creencia de que estamos accediendo al mundo real.

En segundo lugar, el caso de la última dictadura en Argentina presenta algunas particularidades, ya que no contamos con imágenes documentales que den cuenta del universo concentracionario ${ }^{27}$. Más precisamente, no hay imágenes de los centros clandestinos en funcionamiento. Ante la falta de estas imágenes, que son las que tendrían una legitimidad más indiscutible para determinar la veracidad de los hechos, sí hay testimonios ${ }^{28}$ y los documentales, tanto los cinematográficos como los televisivos, suelen recurrir a ellos para construir una verdad. Como marca Jelin, tempranamente "la 'verdad' fue identificándose con la posición de 'afectado/a directo/a”' (2010: 227), primero en la voz de los familiares de las víctimas y luego, vinculado a la palabra de los sobrevivientes de centros clandestinos de detención. En las series que analizamos, como sucede con los programas informativos de televisión, a la ambición veritativa que contiene todo testimonio, se añade la legitimación dada por la televisión, en el sentido común, como instrumento cotidiano de acceso a la realidad (Feld, 2009).

Como explica Raggio (2009), la mayor parte de las imágenes, es decir, lo que nos ha permitido imaginar ese mundo concentracionario, han sido producidas por los sobrevivientes por medio de su testimonio. Incluso, fueron las imágenes audiovisuales que registraron los testimonios durante el juicio a los ex comandantes las que constituyen hasta ahora el mayor archivo audiovisual documental del horror. En términos de Aprea, "la palabra de los testigos siempre aparece como necesaria para suplantar imágenes irrecuperables y para dotar de una dimensión humana a una tragedia que excede el campo de lo mostrable por nuestra sociedad" (2012b:132).

En esta línea, para Feld (2009) el testimonio sobre la desaparición de personas desafía la carencia de imágenes que provocó el sistema represivo. Al no existir imágenes documentales que den cuenta de las condiciones de cautiverio y de los asesinatos clandestinos, el testimonio audiovisual se

26 Baer, a propósito de su análisis sobre el Holocausto, plantea que se ha considerado que la singularidad de ese hecho obligaría a elegir formatos y géneros que pertenezcan "al discurso histórico, frente a la ficción, la dramatización y todo tipo de experimentación estética” (2006:107). Se piensa, entonces, que el lenguaje de ficción siempre añade algo extra que no permite la correcta aprehensión del objeto. Es por esto, entonces, que Baer plantea que el testimonio del testigo se convierte en la forma más productiva para comunicar lo ocurrido, ya que al tiempo que sortea los dilemas de la representación, cumple con el imperativo de memoria (Baer, 2006).

27 Por la existencia de las fotografías tomadas por Basterra durante su detención en la ESMA, entre otros archivos, García y Longoni (2013) consideran que puede decirse que en la Argentina existen imágenes del horror.

28 Incluso, tampoco la sociedad ha tenido acceso directo a documentos oficiales sobre la represión ilegal, lo que también colabora en posicionar a los testimonios como fuentes primordiales para reconstruir esos hechos (Carnovale, 2007; Feld, 2012). 
erige entonces como una presencia que intenta dar cuenta de la ausencia de aquellos que desaparecieron. Como explica la autora a propósito del especial televisivo "Nunca Más" de la CONADEP ${ }^{29}$, frente a esta falta de imágenes documentales, entonces, el foco de credibilidad debió desplazarse hacia las imágenes de los testigos mismos: fundamentalmente, sus rostros ante las cámaras de televisión. La imagen del rostro de los testigos se constituyó así en índice de autenticidad. Relacionado con esto, Baer y Schnettler plantean que "el rostro contiene las huellas del acontecimiento" [...] [y le otorga] "al relato testimonial la fuerza de verdad" (2009:16). Según los autores "el testimonio no solo se fundamenta en la supuesta inmediatez de la fuente histórica, sino también en la cualidad subjetiva, evocativa y empática del relato" (2009:14).

De esta manera, luego de haber hecho estas aclaraciones vinculadas al género documental y al caso específico argentino, analizaremos a continuación cómo las series incluyen testimonios de sobrevivientes para tematizar el cautiverio en centros clandestinos de detención y para describir estos lugares. En cuanto al relato de los testimoniantes, es importante recordar lo que explica Ricoeur (2013): en el discurso hay marcas que dan cuenta del "yo allí". Además de dar fechas, nombres de compañeros y otros datos similares, estas marcas, como veremos a continuación en las series, constituyen un aspecto fundamental del testimonio para construir lo relatado como una verdad, ya que se erigen en cierta manera como "pruebas", dentro de lo que puede llamarse una "retórica empirista" (Martyniuk, 2016:126), que es propia de la narrativa testimonial. Para Ricoeur (2013), “dos de las características fundamentales de los testimonios tienen que ver con la certificación de la realidad de lo relatado y la de experiencia vivida por quien da testimonio que, además de autodenominarse testigo, se afirma en la vivencia concreta de aquello que narra" (Aprea, 2012a: $47,48)$.

En los testimonios presentados en las series pueden identificarse dos grandes cuestiones vinculadas a los lugares de desaparición: el reconocimiento espacial y su marcación. En cuanto a la primera cuestión, advertimos, a su vez, dos modalidades. La primera modalidad, presente en la serie "Ex-ESMA...", está vinculada a la descripción que hacen los sobrevivientes de ruidos; tipos de luz; lugares, como puertas y escaleras; y materiales, que dan cuenta del reconocimiento espacial. En el capítulo "Un átomo en el universo infinito congelado", una sobreviviente, Graciela Daleo, relata:

Me bajan del auto en el playón del Casino de Oficiales, me llevan primero (calculo yo) a una especie de antesala que es, que había después, eso lo vi después, frente al Dorado, donde me tuvieron un rato esperando con la cabeza cubierta con la capucha, ya esposada y engrillada. Después me bajaron al sótano.

Este relato muestra el reconocimiento de una espacialidad específica que puede ser cotejada con las características de la ESMA, así como con la descripción de otros sobrevivientes. La narración en primera persona, que da cuenta del "yo allî", abona a la construcción de lo veritativo y transmite

${ }^{29}$ La Comisión Nacional sobre la Desaparición de Personas (CONADEP) fue creada en 1983 por el presidente Raúl Alfonsín con el objetivo de reconstruir el accionar represivo de la dictadura y así indagar el destino de los desaparecidos. La investigación se cristalizó en un informe final, el "Nunca Más". Para un análisis en profundidad sobre este informe, véase Crenzel $(2008,2010)$. 
una sensación de "testigo ocular". En palabras de Ricoeur, "lo que se atesta es, indivisamente, la realidad de la cosa pasada y la presencia del narrador en los lugares del hecho" (2013:211). Paralelamente, en esta escena se utilizan imágenes para ilustrar los lugares que la testimoniante describe, de modo que estos fragmentos del relato montados en simultáneo con las imágenes actuales del lugar se erigen a modo de prueba de la veracidad de lo relatado.

La segunda modalidad vinculada al reconocimiento de la espacialidad lo encontramos en "El camino de la Justicia". Si bien en este caso se trata del relato de una madre 30 de desaparecidos, lo incluimos aquí ya que es un momento en el cual expone la palabra de ex detenidos desaparecidos. En el capítulo "Nunca más", ella recuerda que, al ser liberados, los sobrevivientes hablaban de la existencia de ciertas marcas que ellos habían dejado en los lugares de cautiverio (como iniciales y nombres en las paredes). Asimismo, comenta el caso de una chica, a quien parafrasea, que hablaba de la existencia de un santo en un lugar determinado del centro clandestino en el que había estado detenida:

Me acuerdo una chica que dijo: "si yo estoy en lo cierto, detrás de esta pared, tiene que haber, arriba, un hueco que tiene un santito", no me acuerdo, si ella...cuál era, "y en ese mismo zócalo tienen que estar mis iniciales que las puse con una lapicera que no escribía", o sea que quedaron, iy estaban! La CONADEP, los que habían ido, miraban ese zócalo ahí y estaban las iniciales de esa persona.

Esta escena también incluye fotografías de archivo de los recorridos, mencionados por la madre, que hizo la CONADEP junto a los sobrevivientes. De esta manera, lo narrado por los sobrevivientes (aquí mediado por la palabra de una madre) señala marcas materiales, objetos y lugares que fueron luego encontrados y reconocidos, y así construidos como pruebas de su paso por allí. La figura de la CONADEP, con el estatuto de autoridad y legitimidad que reviste, funciona también a modo de aval y certificación de lo ocurrido.

En ambas modalidades, a partir de diferentes recursos discursivos, se intenta describir y así recrear una espacialidad específica. En el primer caso, es sobre todo el uso de la primera persona lo que construye como legítima esa historia. En el segundo, la posibilidad de haber chequeado y corroborado la narración y descripción hecha por sobrevivientes, por parte de la CONADEP, es lo que imprime validación.

En cuanto a la segunda cuestión, la marcación de la espacialidad, identificamos también dos modalidades. La primera la encontramos en la serie "Ex-ESMA...": además de los testimonios de sobrevivientes que relatan y describen dónde estuvieron detenidos, aquí se agrega un plus, en el cual los testimoniantes recorren los lugares, no personalmente sino a través de un papel y un marcador (Imagen 1). En algunos momentos a lo largo de la serie se paran frente al plano de la ESMA y dibujan en él su propio recorrido en el lugar o cómo era la distribución espacial en ciertos pisos allí

30 Se trata de Emilia Villares de D’ambra, integrante de Familiares de Desaparecidos y Detenidos por Razones Políticas de Córdoba. 
dentro. Al reconocer el lugar, describirlo y dar cuenta de los recorridos hechos allí, esto se construye como una "prueba" de su paso por la ESMA.

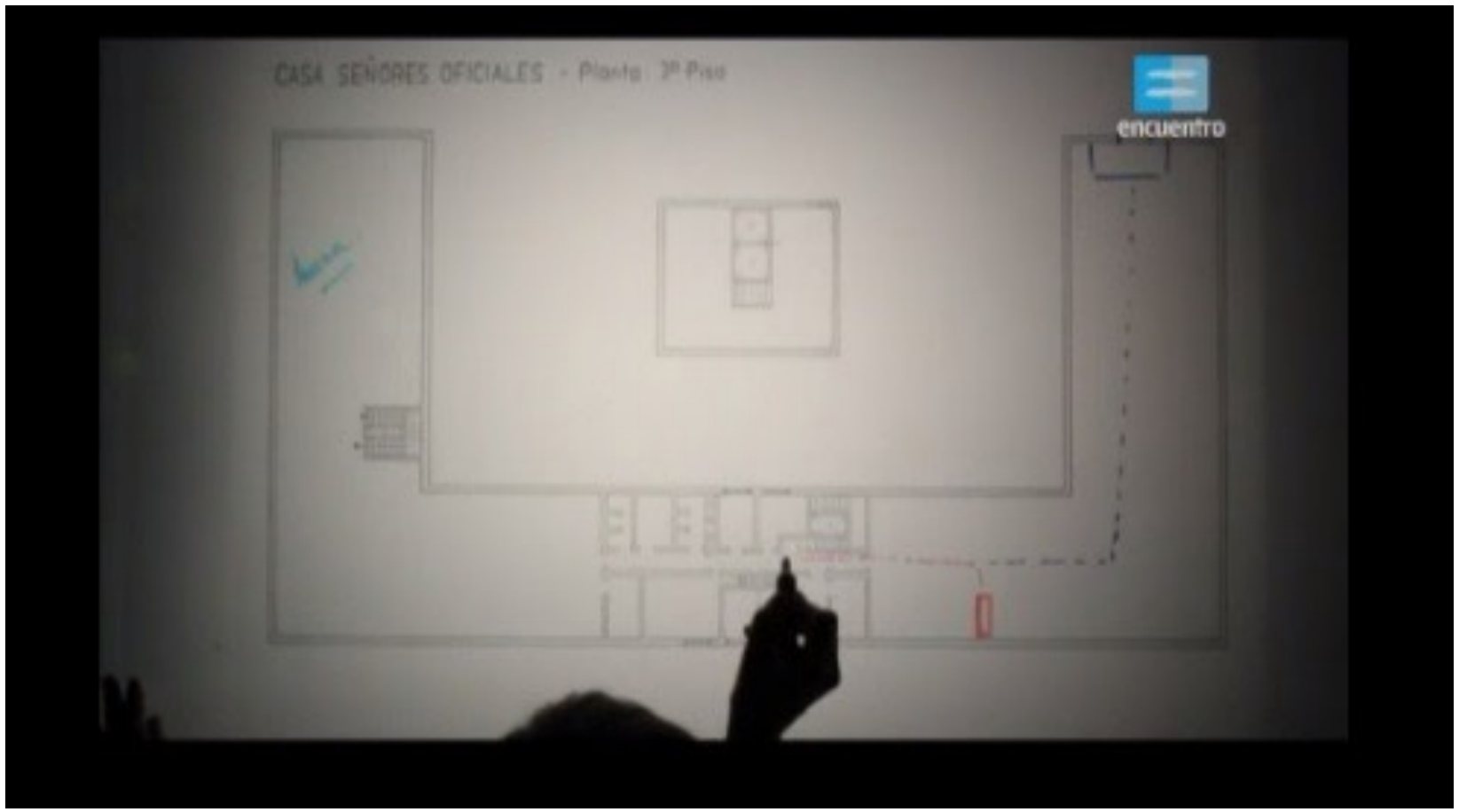

Imagen 1. Capítulo "Sobrevivir". "Ex - ESMA...”.

La segunda modalidad la observamos en "A la sombra del Aconcagua....", donde también se combinan el reconocimiento y la marcación de la espacialidad, pero en este caso en el lugar mismo de los hechos. En el capítulo "Centros clandestinos", los testimoniantes recorren el lugar de su cautiverio, dando descripciones concretas que son cotejadas en ese mismo recorrido con las características que presenta el lugar. El primer testimoniante, Daniel Tagarelli, antes de ingresar a los edificios del predio de la Compañía de Comunicación de Montaña VIII del Ejército ${ }^{31}$ que está recorriendo junto con el juez Raúl Fourcade (ya que se trata de una inspección ocular), aclara que la cuadra en la que él permaneció detenido ya no existe más. No obstante, empieza a describirla, intuyendo que es probable todas tengan por dentro la misma distribución. A medida que el testimoniante relata la disposición concreta de oficinas, camas, baños y sala de tortura, ya no veremos más las imágenes de ese relato que estaba ocurriendo en el exterior (Imagen 2), sino que empiezan a ser proyectadas imágenes de Tagarelli y el juez en el interior de una cuadra, mientras el testimoniante señala con sus manos los distintos lugares reconocidos por él (Imagen 3). Es decir, cuando comienza la descripción en el exterior, antes de ingresar a la cuadra, el testigo ya puede dar cuenta de su distribución espacial. En simultáneo a su relato, vemos escenas que fueron tomadas luego, en donde se corrobora eso que él ya había descrito minutos antes. Esta simultaneidad de relato e imagen del interior del lugar logra transmitir al espectador la sensación de estar chequeando la descripción que

31 Ubicado en la ciudad de Mendoza, allí funcionó un centro clandestino de detención. 
realiza el testimoniante, que da cuenta de su conocimiento del lugar y de su paso por allí. De esta manera, no sólo las imágenes del lugar se construyen como prueba de su relato, sino que la misma edición que realiza el programa televisivo refuerza este aspecto constatativo del discurso.

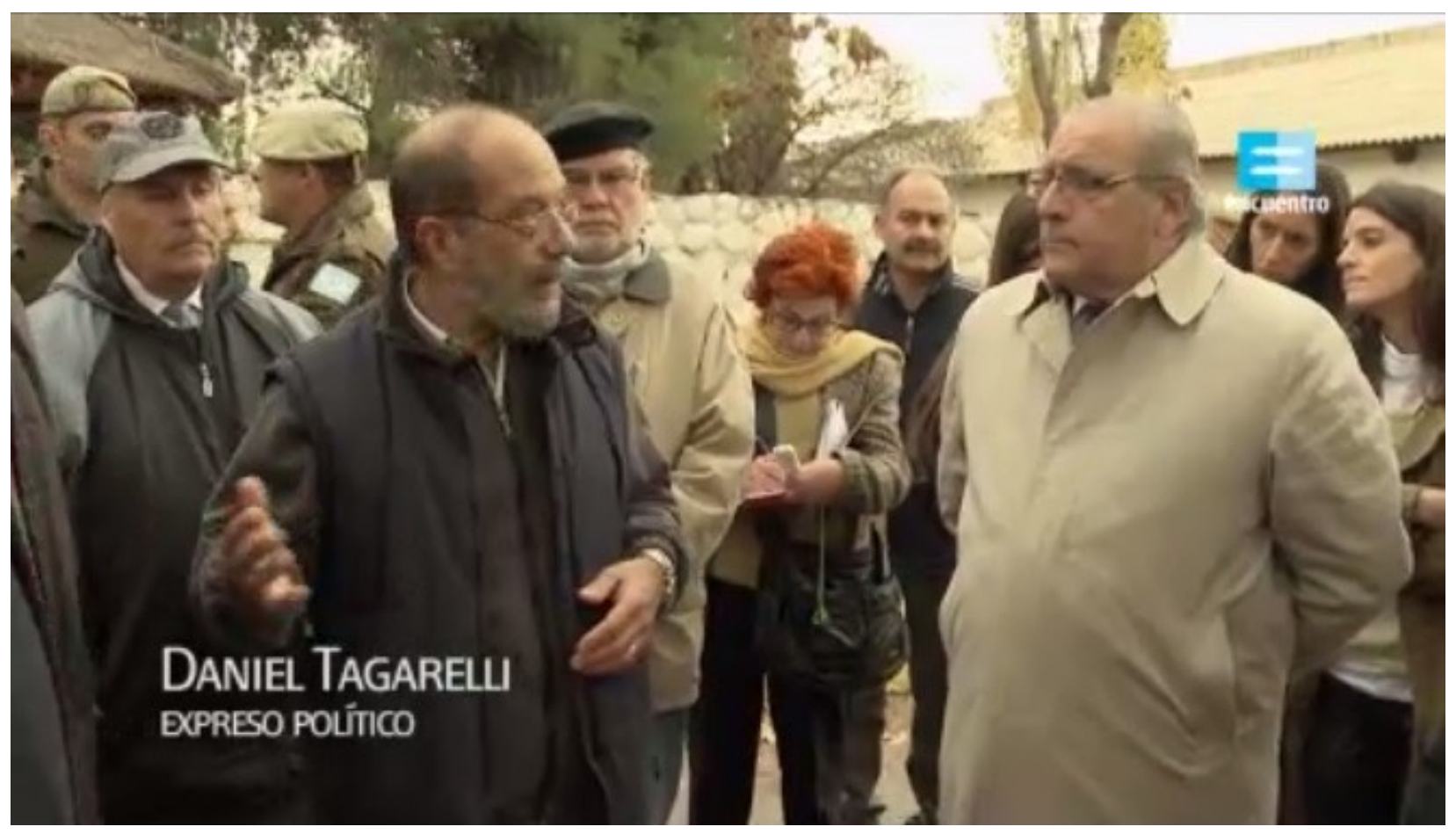

Imagen 2. Capítulo "Centros clandestinos". "A la sombra del Aconcagua....”.

Estas diferentes modalidades en las que aparece el reconocimiento y la marcación de la espacialidad en las series nos conducen a reflexionar sobre el lugar de la materialidad al momento de testimoniar. En estas series pareciera estar presente la idea de que es necesario algún tipo de vínculo con la materialidad para evocar el pasado. Así como se plantea que los lugares ${ }^{32}$ por sí solos no "hablan" (Schmucler, 2006; Feld, 2011), pareciera que los testimonios tampoco lo hacen solos, sino que requieren algún tipo de anclaje material. De un modo evidente, en "A la sombra del Aconcagua...", los testimoniantes se trasladan a los ex centros clandestinos de detención, desde donde dan su testimonio ante la cámara. Esta modalidad, presente en programas televisivos anteriores $^{33}$, no obstante, presenta una novedad ya que en uno de los casos esto forma parte de una inspección ocular judicial. Es decir, este recurso ya utilizado de recorrer el lugar de cautiverio mientras se da testimonio, aquí toma otro sentido al ser parte de una situación judicial.

\footnotetext{
32 Para un análisis de las diferentes concepciones existentes sobre la relación entre la materialidad de los ex centros clandestinos y su sentido, véase D'Ottavio (2017).

33 Nos referimos a los programas analizados por Feld (2009), "El diario del golpe" y "Regreso al infierno", ambos de 2006, que fueron emitidos en el marco del trigésimo aniversario del golpe de Estado.
} 


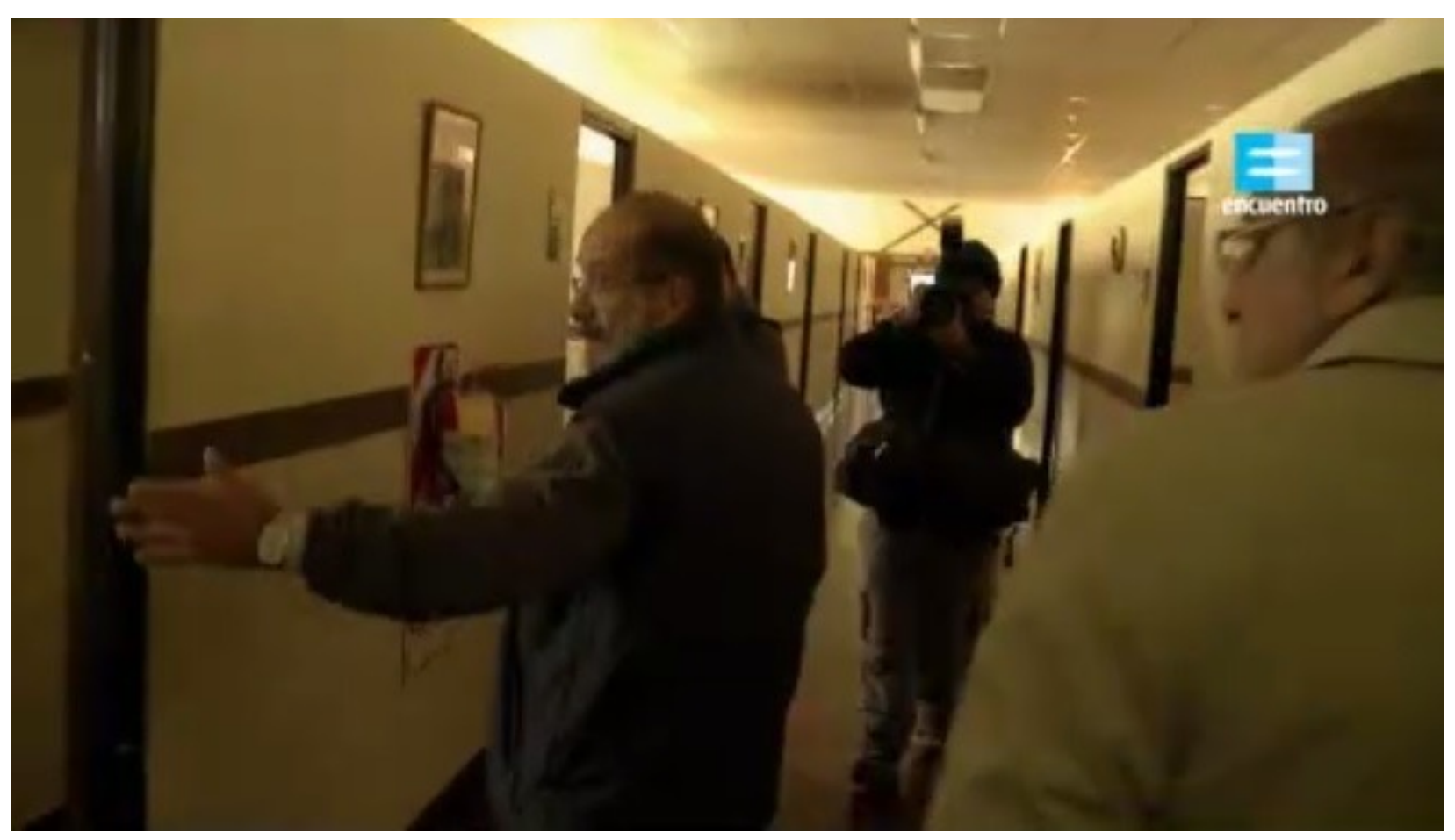

Imagen 3. Capítulo "Centros clandestinos". "A la sombra del Aconcagua....".

También en "El camino de la justicia" aparece el lugar del cautiverio como trasfondo del relato de los sobrevivientes, aunque aquí no veremos a los testimoniantes recorrerlo, ni identificar lugares allí dentro. Por el contrario, en el caso del sobreviviente José López, él está sentado del lado de afuera y al ser de día, la iluminación es natural, como si se buscara remarcar la diferencia entre su paso por allí durante su cautiverio, donde permanecía detenido y a oscuras o con luz artificial y, su testimonio en el presente. Si bien la mayoría de los testimonios suceden en las instalaciones del ex D234, esto no es precisado por el graph ni por el narrador, aunque sí advertible por un ojo familiarizado con la fisionomía del lugar. Aunque la ubicación no es explicitada para el espectador, pareciera ser importante que el relato transcurra allí, como si la materialidad del lugar fuera la posibilitadora y al mismo tiempo avaladora del testimonio. También diferenciándose de algunos ciclos televisivos de los 2000, es importante remarcar que aquí se trata no sólo de un ex centro clandestino de detención, sino de un sitio de memoria ya que, luego de sancionarse en 2006 la Ley provincial de la Memoria 9286, se emplazaron allí la Comisión y el Archivo Provincial de la Memoria y, en 2008, se inauguró el "Museo de Sitio".

En el caso de "Ex-ESMA..." este vínculo con la materialidad es más sutil ya que los testimoniantes no se desplazan hacia un ex centro clandestino de detención para relatar su historia. En esta serie, que transcurre en un estudio, los testimonios siempre tienen lugar en una silla, la

\footnotetext{
${ }^{34}$ El D2, Departamento de Informaciones de la Policía de Córdoba, fue utilizado como centro clandestino de detención entre 1974 y 1978.
} 
misma a lo largo de todos los capítulos. Esta silla tiene una presencia protagónica, ya que se emplaza en un ambiente donde no hay nada más, sólo un fondo negro y el testimoniante (Imagen 4). Esta puesta en escena sobria, despojada y austera genera que nuestra mirada y atención se dirija únicamente a la silla y a la persona sentada allí.

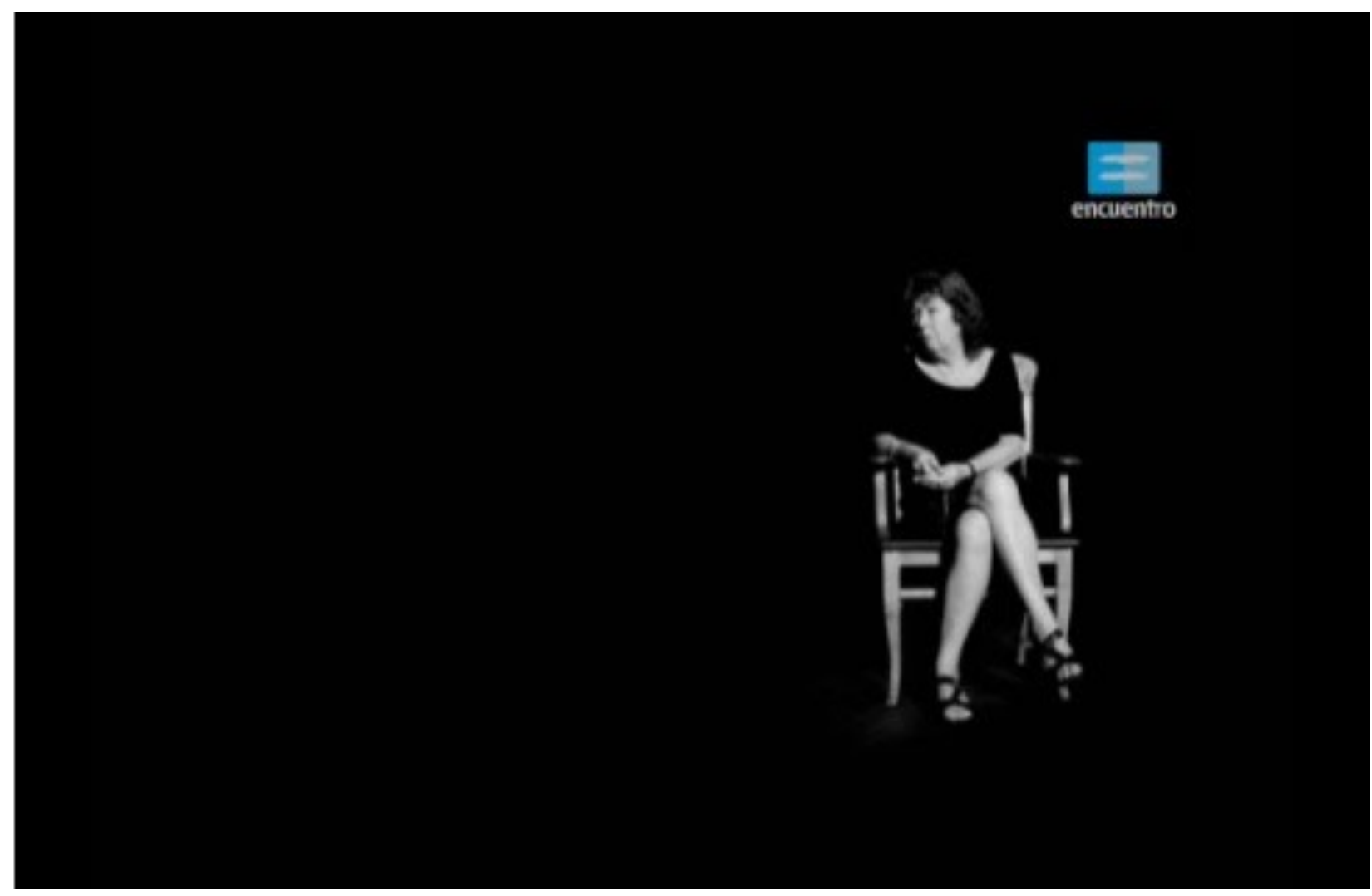

Imagen 4. Capítulo "Vida aparecida". "Ex - ESMA...".

Nos detenemos un momento en la silla no sólo porque resulta interesante marcar algunas decisiones estéticas de la serie, sino porque consideramos cumple una función más precisa aquí. Es importante señalar que esta no es una silla cualquiera: su diseño formal y antiguo, junto con su estructura de madera nos remiten al contexto judicial y no de la actualidad, sino de los ochenta (Imagen 5). Se trata de un mobiliario que perfectamente podríamos encontrar en dependencias estatales de esos años, muy distinto a los actuales que suelen ser más simples y de plástico. Sus propias características nos marcan que allí sucederá algo relacionado con esa época. La silla, entonces, nos conecta con un contexto histórico y, también, con el ámbito estatal, ya que no es una silla típica de estudio de televisión, simple y masiva. Este mobiliario, entonces, logra ubicarnos en un registro más cercano al testimonio judicial, aunque se trate de televisión. Podemos pensar, entonces, que la elección de la silla no es fortuita y ella misma se erige simbólicamente como testigo de una época y es allí donde los sobrevivientes relatan su experiencia. La silla se construye así como la 
portadora de la palabra. Asimismo, como hemos mencionado, en esta serie los testimoniantes en algunas ocasiones acompañan su relato con la marcación de un plano de papel: de pie, se acercan a un dibujo de la planta del Casino de Oficiales para señalar con un marcador lugares, disposiciones y recorridos que forman parte de su testimonio.

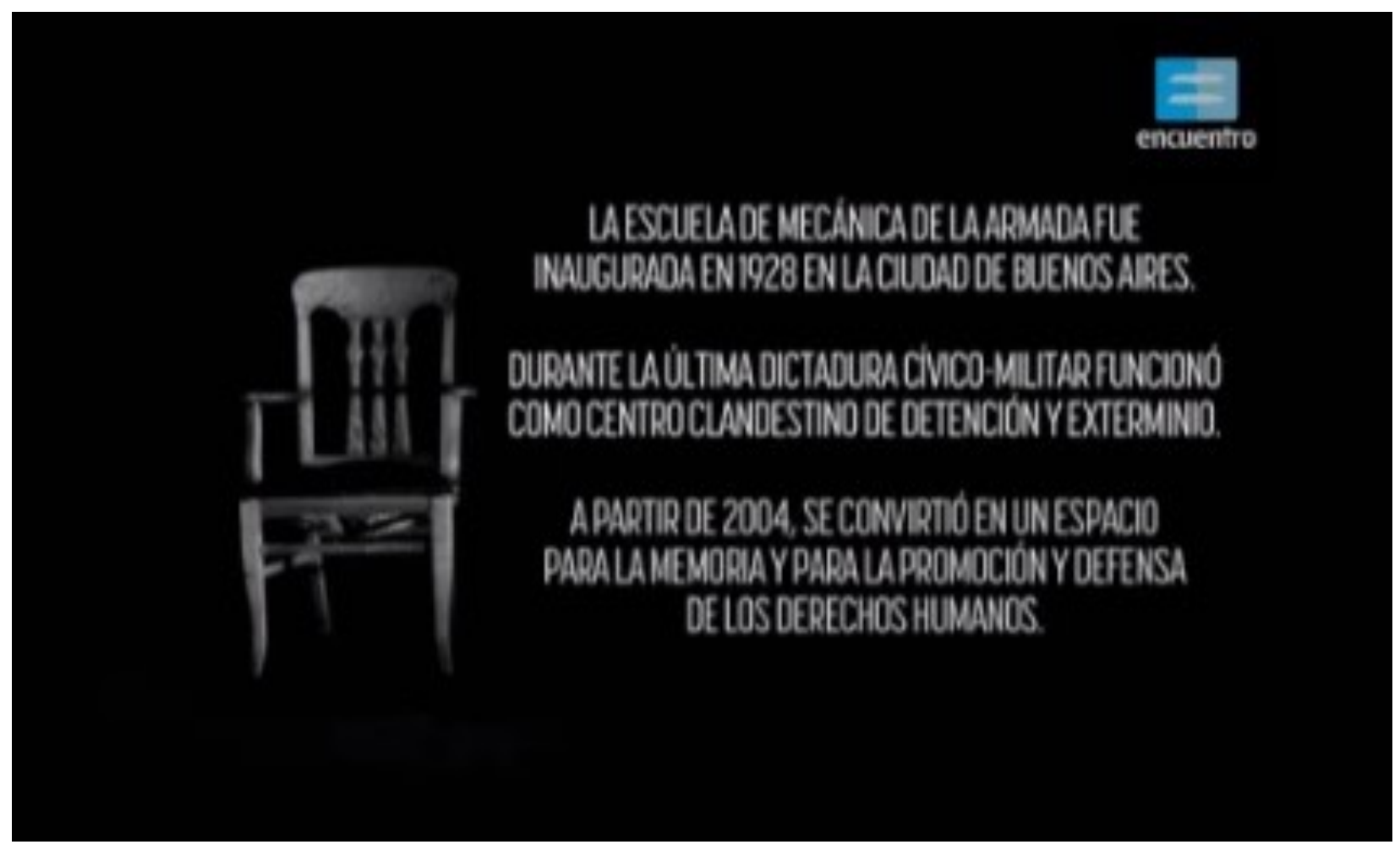

Imagen 5. Capítulo "Memoria y futuro". "Ex - ESMA...”.

De esta manera, la materialidad, específicamente los ex centros clandestinos de detención, la silla y el plano de papel, se presentan como facilitadores de un relato, como necesarios para la evocación del pasado, ya que serían el vínculo concreto con los hechos mismos. Paralelamente, los ex centros clandestinos serían también una prueba, un aval, y la dotación de legitimidad al testimonio, por ser aquello justamente de lo único que puede haber imágenes en la actualidad. Estos lugares, aún con el paso de los años, siguen en pie, algunas de sus huellas persisten y se pueden ver. Esta cualidad tangible de lo material y la posibilidad de obtener imágenes de estos lugares contribuyen, a su vez, a darle un nuevo valor de verdad al relato, que se complementa, como vimos anteriormente, con el estatuto de verdad intrínseco al testimonio mismo. La importancia de la materialidad en la puesta televisiva está dada, entonces, no sólo porque permite evocar el pasado, sino también porque en el ejemplo de los ex centros clandestinos, se trata de las pocas cosas que pueden funcionar como imágenes para el espectador, teniendo en cuenta la enorme centralidad de la imagen como fuente, prueba y vehículo de conocimiento, en términos de Baer (2005) y como legitimadora de un relato, cuestiones que hemos esbozado al comienzo de este apartado. 
Así como los testimonios colaboran en la atribución de sentido a las materialidades (D’Ottavio, 2017), son estos restos, estos lugares los que dotan de legitimidad a la palabra de los sobrevivientes. La contundencia de lo material, fundamentalmente del interior de los centros clandestinos, pero también de cuestiones más sutiles como las marcaciones en el plano de papel o las imágenes exteriores de lo que era el D2 en Córdoba, potencia la voz de los testimonios, que difícilmente pueden anclarse en otro tipo de pruebas, por lo clandestino de los crímenes padecidos. Aunque las arquitecturas y los objetos requieran un trabajo (generalmente dificultoso) de lectura para su interpretación, "aquello que está fosilizado en ellos aparece como objetivo" (D'Ottavio, 2017:138). De manera que es esta objetividad (de modo análogo a lo que sucede con la inclusión en las series de material de archivo, por ejemplo) la que es buscada por los documentales televisivos para que la palabra subjetiva de los testimonios se respalde y sustente.

El vínculo entre materialidad y testimonio, lejos de presentarse con tensiones, en estas series aparece como algo sin conflictos. Entre ambos hay una linealidad y una conexión directa, sin ambigüedades ni dudas. La materialidad aparece como sustento del relato, como prueba y verificación de la palabra. Y los posibles vacíos, tensiones, dudas que pudieran existir no son explicitados. En algunos casos puntuales, como el de Daniel Taragerilli y el del relato de la madre Emilia Villares de D'ambra, la materialidad se da estrictamente como prueba. En otros, el lugar y la espacialidad, aparecen como escenario de enunciación y legitimidad.

Por último, podemos pensar que, aunque se advierte una necesidad de establecer un vínculo con la materialidad, esto no necesariamente obliga a revivir el horror. A propósito de este tema son importantes las reflexiones de LaCapra (2005), Baer y Schnettler (2009) y Arfuch (2013), ya que, para estos autores, las personas al dar testimonio sobre hechos traumáticos vuelven en cierta manera a vivir esos acontecimientos. Según LaCapra (2005) cuando esto sucede, todo ocurre como si no hubiera diferencia entre el pasado y el presente. Sin embargo, el autor señala que una persona puede no limitarse "a volver a vivir el pasado o ponerlo en acto compulsivamente sino que, en cierta medida, lo repasa y posiblemente lo elabora" (2005:107) ${ }^{35}$. Un ejemplo en el cual los testimoniantes revivirían el horror sería, según LaCapra36, el film Shoa, dado que allí Lanzmann, realiza un "intento

35 En este sentido, también Bacci, Capurro Robles, Oberti y Skura (2014) plantean que el testimonio “contiene potencialmente un aspecto reparador en tanto coloca en un lugar de agentes a quienes son interpeladas en primera instancia sólo como víctimas" (2014:128). Balardini, Oberlin, y Sobredo (2011) postulan que el testimonio tiene "una enorme potencia como instrumento de elaboración subjetiva, tanto para el testigo como para la sociedad en su conjunto" (2011:175). Por su parte, Arfuch plantea la dimensión terapéutica del relato, es decir "la narración como trabajo de duelo" (2013:76) y la importancia de las narrativas testimoniales y autobiográficas para "la elaboración de la experiencia de la última dictadura militar” (2013:77). Incluso, también se señala la dimensión colectiva implicada en este proceso: para Aprea "la 'comunidad afectiva' que se genera en la evocación permite atenuar la experiencia traumática" (2015: 202).

36 Vale aclarar que para LaCapra (2005) los procesos de repetición compulsiva (acting out) y elaboración interactúan y "se presentan bajo formas híbridas o combinadas” (2005:107). El autor realiza un extenso análisis de este tema que aquí sólo mencionamos brevemente para analizar las implicancias del modo en que aparece el testimonio en las series televisivas en cuestión y, esta distinción, la utilizamos de modo analítico, sin dejar de considerar que son procesos interactivos y no dicotómicos, como aclara LaCapra. 
de transportar al sobreviviente de nuevo al pasado, a la escena de la victimización y el trauma - en sentido figurado y, a veces, literal-“ (2005:116). ${ }^{37}$

El caso de las series que analizamos consideramos que puede encuadrase más bien en otra dirección. Si bien es cierto que en dos de las series los sobrevivientes se trasladan al lugar de cautiverio, hay una distancia que los separa de ellos. Así como en "A la sombra del Aconcagua..."el visitar el lugar del horror estaba "mediado" por ser una inspección judicial, en "El camino de la justicia" esta mediación, esta distancia del horror, está dada por su nuevo estatuto como sitio de memoria y por las diferentes estrategias de la puesta en escena desplegadas por la serie que recién hemos mencionado (el testimonio sucede en el exterior, con luz natural, etc.) ${ }^{38}$. En el caso de "ExESMA...", esta distancia es aún mayor ya que el plano de papel es el que actúa como vínculo con el pasado, evitando que los sobrevivientes se acerquen al lugar de los hechos. Es decir, dada la inclusión de ciertas mediaciones con lo acontecido podríamos pensar que existe una búsqueda, por parte de estas series, por no revivir el trauma.

\section{PALABRAS FINALES}

A lo largo de este trabajo hemos analizado cómo las series de Canal Encuentro han puesto en escena testimonios de sobrevivientes en relación con los lugares de desaparición. Luego de un breve análisis del canal emisor y de los documentales televisivos, hemos identificado que las series incluyen testimonios que fundamentalmente realizan un reconocimiento y una marcación de la espacialidad transitada en el cautiverio. A su vez, hemos observado que cada una de estas acciones presenta dos modalidades fundamentales. En el primer caso, tanto a partir del uso de la primera persona como mediante la corroboración de lo dicho por una autoridad como la CONADEP, se construye como legítimo y verídico el relato de los sobrevivientes sobre los lugares descriptos. En el segundo caso, la marcación de la espacialidad se da principalmente a través del uso de plano de papel y del recorrido por el lugar mismo de los hechos.

La hipótesis que propusimos consiste en pensar que en estas series pareciera estar presente la idea de que es necesario algún tipo de vínculo con la materialidad para evocar el pasado. Paralelamente propusimos que esta materialidad, no obstante, no conlleva necesariamente a que los testimoniantes revivan el horror sufrido. Sin que haya sido nuestro objetivo analizar la particularidad

\footnotetext{
${ }^{37}$ Exceden los objetivos de nuestro trabajo el análisis de la película "Shoa" de Lanzmann. Sólo diremos que en los debates en torno a las posibilidades o no de representar los crímenes del nazismo, esta película se erigió como el símbolo de aquella postura que plantea que no deben reproducirse directamente imágenes de archivo, como sí lo hacía el documental emblemático "Noche y niebla", sino testimonios. Para un abordaje más en profundidad del film "Shoa", véase LaCapra $(2005,2009)$ y Baer (2006), entre otros

38 Vale aclarar que en estas dos series también aparecen situaciones en las cuales los testimoniantes recorren el lugar donde estuvieron detenidos o exponen su relato desde allí. No obstante, consideramos que tanto el testimonio brindado en un contexto judicial ("A la sombra del Aconcagua...") como aquel que se da en el exterior de un centro clandestino ("El camino de la justicia") pueden entenderse como una búsqueda por plantear un modo diferente de acceder a lo sucedido, y es por esto que hemos tomado estos ejemplos que representan una alternativa en la puesta en escena para nuestro análisis.
} 
de cada persona que brindó su testimonio, sí pudimos examinar algunas estrategias implementadas por las series que consideramos buscan establecer una distancia con el horror. Inspecciones judiciales, sitios de memoria, puestas en escena distanciadas del interior del lugar y planos de papel para representar trayectorias y lugares se convirtieron en mediaciones fundamentales.

Justamente, lo que creemos que intentan estas series es traer como protagonista a esa distancia temporal que señalaba LaCapra (2005) como necesaria para la elaboración. El objetivo sería remarcar esa diferencia entre el pasado y el presente y por eso se utilizan los recursos y mediaciones que hemos mencionado en cada caso a fin de que el relato no sea un mero revivir el horror, atado al pasado, sino más bien, un proceso que tome distancia, que trate de elaborar esa experiencia. De esta manera, podemos pensar que estos documentales, aunque planteen la necesidad de un anclaje material para la evocación del pasado, buscan construir distancias con el horror, y consideran entonces, en términos de Jelin, que el testimonio da la posibilidad de "regresar a la situación límite, pero también regresar de la situación límite" (2012:124). 


\section{BIBLIOGRAFÍA}

AdoRnO, Theodor (1962). Prismas. La crítica de la cultura y la sociedad. Barcelona: Ediciones Ariel.

Almirón, Alejandra (2003). El tiempo y la sangre. Argentina: Sonia Severini y Cine Ojo.

AMADO, Ana (2005). "Las nuevas generaciones y el documental como herramienta de historia". AAVV. Historia, género y política en los 70. Buenos Aires: Feminaria.

ApreA, Gustavo (2012a). "Documental, historia y memoria: un estado de la cuestión". APREA, Gustavo (ed.). Filmar la memoria. Los documentales audiovisuales y la re-construcción del pasado. Los Polvorines: Universidad Nacional de General Sarmiento: 19-85.

ApreA, Gustavo (2012b). "Los usos de los testimonios en los documentales audiovisuales argentinos que reconstruyen el pasado reciente". APREA, Gustavo (ed.). Filmar la memoria. Los documentales audiovisuales y la re-construcción del pasado. Los Polvorines: Universidad Nacional de General Sarmiento: 121-152.

Aprea, Gustavo (2015). Documental, testimonios y memorias. Miradas sobre el pasado militante. Buenos Aires: Manantial.

ARFuCH, Leonor (2013). Memoria y autobiografía. Exploraciones en los límites. Buenos Aires: Fondo de Cultura Económica.

ArRECHE, Araceli Mariel. "Violencia y memoria. Sentido(s) del espacio en cortometrajes de hijos de desaparecidos”. Revista TOMA UNO 4 (2015): 191-198.

ÁviLA, Benjamín (2014). Ex - ESMA. Retratos de una recuperación. Argentina: Habitación 1520 para Canal Encuentro.

Bacci, Claudia, Capurro Robles, María, Oberti, Alejandra y Skura, Susana. "Entre lo público y lo privado: los testimonios sobre la violencia contra las mujeres en el terrorismo de Estado en Argentina”. Clepsidra. Revista Interdisciplinaria de Estudios sobre Memoria 1 (2014): 122-139.

BAER, Alejandro (2005). El testimonio audiovisual. Imagen y memoria del Holocausto. Madrid: CIS y Siglo XXI.

BAER, Alejandro (2006). Holocausto. Recuerdo y representación. Madrid: Losada.

BAER, Alejandro, SCHNETTLER, Bernt (2009). "Hacia una metodología cualitativa audiovisual. El vídeo como instrumento de investigación social”. MERLINO, Aldo (ed.). Investigación Cualitativa en las Ciencias Sociales: Temas y problemas. Buenos Aires: Cengage Learning: 2-38.

BALARDini, Lorena, OBERlin, Ana, SOBRedo, Laura (2011). "Violencia de género y abusos sexuales en centros clandestinos de detención. Un aporte a la comprensión de la experiencia argentina". AA. VV. Hacer justicia. Nuevos debates sobre juagamiento de crímenes de lesa bumanidad en Argentina. Buenos Aires: Siglo XXI: 167-226. 
CARnOVAle, Vera (2007). "Aportes y problemas de los testimonios en la reconstrucción del pasado reciente en la Argentina”. FrANCO, Marina, LEvín, Florencia (ed.). Historia reciente: perspectivas y desafíos para un campo en construcción. Buenos Aires: Paidós: 155-181.

Comisión Nacional sobre la Desaparición de Personas (CONADEP) (1984). Nunca Más. Informe de la Comisión Nacional sobre la Desaparición de Personas. Buenos Aires: Editorial Universitaria de Buenos Aires.

ConadeP (1984). Nunca Más. Argentina: Canal 13.

CORTE, Malena. "Reflexiones en torno al propósito educativo de Canal Encuentro". Question 51 (2016): 360-375.

CRENZEL, Emilio (2008). La bistoria política del Nunca más: la memoria de las desapariciones en la Argentina. Buenos Aires: Siglo XXI.

Crenzel, Emilio (2010). "La víctima inocente: de la lucha antidictatorial al relato del Nunca más". Crenzel, Emilio (ed.). Los desaparecidos en la Argentina. Memorias, representaciones e ideas (1983-2008). Buenos Aires: Editorial Biblos: 65-83.

D’OtTAVIO, Adriana (2017). "Si algo es capaz de decir, de sí mismo o de algo, algo: intervenciones expertas sobre las materialidades de los ex centros clandestinos de detención, tortura y exterminio de la Ciudad de Buenos Aires". Tesis de Maestría. Buenos Aires: Universidad Nacional de San Martín.

Didi Huberman, Georges (2004). Imágenes pese a todo. Memoria visual del Holocausto. Barcelona: Paidós.

FELD, Claudia (2002). Del estrado a la pantalla: las imágenes del juicio a los ex comandantes en Argentina. Madrid: Siglo Veintiuno Editores.

FELD, Claudia (2009). “'Aquellos ojos que contemplaron el límite’: la puesta en escena televisiva de testimonios sobre la desaparición”. FELD, Claudia, STITES MOR, Jessica (eds.). El pasado que miramos. Buenos Aires: Paidós: 77-109.

FELD, Claudia (2011). "La memoria en su territorio”. Fleury, Béatrice, WALTER, Jacques (eds.). Memorias de la piedra. Buenos Aires: Ejercitar la memoria editores: 9-17.

FELD, Claudia (2012). "Las capas memoriales del testimonio. Un análisis sobre los vínculos entre espacio y relatos testimoniales en el Casino de Oficiales de la ESMA". HufFSCHMID, Anne, Durán, Valeria (eds.). Topografías conflictivas. Memorias, espacios y ciudades en disputa. Buenos Aires: Trilce: $335-365$.

FELD, Claudia. "Preservar, recuperar, ocupar. Controversias memoriales en torno a la ex-esma (1998-2013)". Rev. Colomb. Soc. 1 (2017): 101-131.

Friedlander, Saúl (2007). "Introducción". Friedlander, Saúl (ed.). En torno a los límites de la representación. El nazismo y la solución final. Quilmes: Universidad Nacional de Quilmes. 
GARCíA, Luis Ignacio, LONGONI, Ana (2013). "Imágenes invisibles: acerca de las fotos de desaparecidos". BLEJMAR, Jordana, FORTUNY, Natalia, GARCíA, Luis Ignacio (eds.). Instantáneas de la memoria. Fotografía y dictadura en Argentina y América Latina. Buenos Aires: Libraria: 25-44.

GiUfFrA, María (2005). La Matanza. Argentina: s/d.

GUGLIELMUCCI, Ana (2013). La consagración de la memoria: una etnografía acerca de la institucionalización del recuerdo sobre los crimenes del terrorismo de Estado en la Argentina. Buenos Aires: Antropofagia.

Huyssen, Andreas (2007). En busca del futuro perdido. Cultura y memoria en tiempos de globalización. Mexico: Fondo de Cultura Económica.

Huyssen, Andreas (2009). “Prólogo. Medios y memoria”. FELD, Claudia, STITES MOR, Jessica (eds.). El pasado que miramos. Buenos Aires: Paidós.

JELIN, Elizabeth (2010). “¿Víctimas, familiares o ciudadanos/as? Las luchas por la legitimidad de la palabra”. CREnzel, Emilio (ed.). Los desaparecidos en la Argentina. Memorias, representaciones e ideas (1983-2008). Buenos Aires: Biblos: 227-249.

JELIN, Elizabeth (2012). Los trabajos de la memoria. Lima: Instituto de Estudios Peruanos.

LACAPRA, Dominick (2005). Escribir la historia, escribir el trauma. Buenos Aires: Nueva visión.

LACAPRA, Dominick (2009). Historia y memoria después de Auschwitz. Buenos Aires: Prometeo.

LanZMAnN, Claude (1985). Shoa. Francia: Faure, Brigitte.

MARTYNIUK, Claudio (2016). Ensayo sobre el testimonio. Ruina y escritura. Buenos Aires: La cebra.

Ministerio de Educación y Deportes de la ArgentinA. Portal educativo.

NiCHOLS, Bill (2011). La representación de la realidad. Cuestiones y conceptos sobre el documental. Barcelona: Paidós.

NiNEY, François (2009). Le documentaire et ses faux-semblants. París: Klincksieck.

OliverA, Héctor (1986). La noche de los lápices. Argentina: Ayala, Fernando y Sessa, Alejandro.

Puenzo, Luis (1985). La historia oficial. Argentina. Puenzo, Nora, Puenzo, Luis, PIÑEYro, Marcelo.

RAGGIO, Sandra (2009). "La noche de los lápices: del testimonio judicial al relato cinematográfico". FELD, Claudia, STITES Mor, Jessica (eds.). El pasado que miramos. Buenos Aires: Paidós: 45-76.

RANCIÈRE, Jacques (2013). El espectador emancipado. Buenos Aires: Manantial.

RESNAIS, Alain (1956). Noche y niebla. Francia: Dauman, Anatole.

Ricoeur, Paul (2013). La memoria, la historia, el olvido. México: Fondo de Cultura Económica.

Rosa Claudio, SeIn, Santiago (2015). El camino de la justicia. Argentina. Bonaparte Cine para Universidad Nacional de Córdoba, SRT multimedio y Canal Encuentro. 
SCHMUCLER, Héctor (2006). "La inquietante relación entre lugares y memoria". Uso público de los sitios históricos para la transmisión de la memoria. Buenos Aires: Memoria Abierta.

SepúlvedA, Rodrigo (2015). A la sombra del Aconcagua. Historia del terrorismo de Estado en Mendoza. Argentina: Liberar Contenidos para Canal Encuentro.

SEPúlvedA, Rodrigo, AgüEro, Cecilia (2006). 7746 Legajo CONADEP. Argentina: Sepúlveda, Rodrigo y Faiozzo, Belén.

SepúlvedA, Rodrigo, SAntos, Fernanda (2001). D2. Argentina: Novelli, Ciro y Santos, Fernanda.

SMERLING, Tamara (2015). La otra pantalla: educación, cultura y televisión. 2005-2015, una década de Canal Encuentro, Pakapaka y las nuevas señales educativas. Buenos Aires: Ministerio de Educación de la Nación.

S/R (2006). El diario del golpe. Argentina: Telefé.

S/R (2006). Regreso al infierno- Telenoche. Argentina: Canal 13.

Traverso, Enzo (2001). La historia desgarrada. Ensayo sobre Auschwitz y los intelectuales. Barcelona: Herder.

WiESEL, Elie (1985). "Préface: Au nom d'une souffrance sans nom". Insdorf, Annette (ed.). L’holocauste a l'ecran. Paris: Cerf. 